\title{
PEMODELAN PREDIKSI KUAT TEKAN BETON UMUR MUDA MENGGUNAKAN H2O'S DEEP LEARNING
}

\author{
Stefanus Santosa ${ }^{1, *)}$, Suroso $^{1)}$, Marchus Budi Utomo ${ }^{1)}$, Martono ${ }^{1)}$, Mawardi ${ }^{1)}$ \\ 1) Jurusan Teknik Sipil Politeknik Negeri Semarang, \\ Jl. Prof H. Sudarto, S.H. Tembalang Semarang 50275 \\ ${ }^{*}$ Email : stefanus.santosa@polines.ac.id
}

\begin{abstract}
Artificial Neural Network (ANN) is a Machine Learning (ML) algorithm which learn by itself and organize its thinking to solve problems. Although the learning process involves many hidden layers (Deep Learning) this algorithm still has weaknesses when faced with high noise data. Concrete mixture design data has a high enough noise caused by many unidentified / measurable aspects such as planning, design, manufacture of test specimens, maintenance, testing, diversity of physical and chemical properties, mixed formulas, mixed design errors, environmental conditions, and testing process. Information needs about the compressive strength of early age concrete (under 28 days) are often needed while the construction process is still ongoing. ANN has been tried to predict the compressive strength of concrete, but the results are less than optimal. This study aims to improve the ANN prediction model using an H2O's Deep Learning based on a multi-layer feedforward artificial neural network that is trained with stochastic gradient descent using backpropagation. The H2O's Deep Learning best model is achieved by 2 hidden layers50 hidden neurons and ReLU activation function with a RMSE value of 6,801. This Machine Learning model can be used as an alternative/ substitute for conventional mix designs, which are environmentally friendly, economical, and accurate. Future work with regard to the concrete industry, this model can be applied to create an intelligent Batching and Mixing Plants.
\end{abstract}

Kata kunci : machine learning, H2O's deep learning, prediction, early age concrete compressive strength

\section{PENDAHULUAN}

\section{Latar Belakang dan Permasalahan}

Dalam dunia rekayasa khususnya teknik sipil, desain campuran (mix design) beton yang dilakukan di laboratorium secara manual memiliki banyak kelemahan. Proses desain tersebut dilakukan dengan berbagai komposisi campuran dan pengujian secara destruktif. Hal ini membutuhkan biaya yang besar dan akurasinya kurang. Masalah yang lebih kompleks lagi berkaitan dengan kebutuhan untuk mengetahui kekuatan beton secara tepat pada umur muda, yakni 3, 7, 14 dan 28 hari. Diperlukannya informasi kekuatan beton umur muda karena sering terjadi pembebanan sebelum beton memiliki kekuatan optimal. Grafik standar kekuatan beton muda tidak begitu saja bisa diandalkan akurasinya karena keragaman sifat fisik, kimiawi bahan campuran, dan kondisi lingkungan saat proses pencampuran, transportasi, dan pengerasan yang sangat beragam. 
Pengujian beton berumur muda juga tidak mudah dilakukan karena sangat dipengaruhi kondisi sekitarnya termasuk perlakukan saat proses pengerasan hingga pengujian.

Berkaitan dengan hal tersebut proses rekayasa (engineering) sangat membutuhkan peran komputasi untuk memperoleh akurasi dan kehandalan yang tinggi. Kompetisi yang ketat di dunia industri menuntut siklus desain yang pendek yang pada gilirannya bergantung pada simulasi numerik untuk mengurangi pengujian prototipeprototipe secara fisik.

Saat ini telah berkembang disiplin ilmu yang disebut Computational Engineering. Computational Engineering adalah bidang multidisiplin baru dan sedang berkembang pesat yang menerapkan metode perhitungan dan analisis komputasional yang canggih terhadap proses rekayasa. Disiplin ilmu ini menggunakan komputer untuk memecahkan masalah desain- desain penting untuk berbagai industri (Takisawa, 2014), (University of Texas. 2018).

\section{Computational Engineering}

berkaitan dengan pengembangan dan penerapan model komputasi dan simulasi yang sering digabungkan dengan komputasi kinerja tinggi untuk memecahkan masalah fisik yang kompleks yang timbul dalam proses analisis dan desain.

Menurut Abolpour dalam penelitiannya tentang model estimasi kuat tekan beton, metode konvensional untuk menentukan desain campuran beton lebih didasarkan pada ketidakpastian, bergantung pada gagasan ahli, dan formulasi matematis yang kurang tepat. Desain campuran beton merupakan hal yang sangat sulit dan sensitif. Hal ini disebabkan oleh (1) perilaku komponen yang tidak pasti, (2) ketidaktepatan dan ketidakjelasan dalam berbagai parameter desain, dan (3) aspek estimasi yang terdapat dalam berbagai kode standar desain yang berbeda. Satu desain campuran hanya efektif untuk satu kuat tekan saja. Setiap kali produksi yang melibatkan sedikit variasi karakteristik material yang berbeda membutuhkan desain baru. Saat desain diterapkan sering terjadi kondisi di laboratorium/ lapangan sangat berbeda dengan formula desain yang dibuat. Kesulitan seperti ini menyebabkan hasil prediksi kuat tekan tidak akurat. Hal ini menunjukkan bahwa desain campuran konvensional hanya sekedar estimasi saja. Dengan demikian penting untuk merumuskan prosedur estimasi desain campuran dengan cara yang lebih alami, humanistik, dan lebih ilmiah. (Abolpour, 2013).

Guna mengatasi permasalahan Civil Engineering tersebut di atas maka peneliti menggunakan pendekatan Computational Engineering berbasis komputasi cerdas. Neural Network (NN) merupakan salah satu algoritma komputasi cerdas yang mampu belajar sendiri dan mengorganisasikan pemikirannya untuk memecahkan masalah. Algoritma dasar NN yang digunakan pada penelitian sebelumnya hanya memiliki satu hidden layer saja. Keterbatasan jumlah hidden layer ini 
dapat menyebabkan peningkatan kesalahan dalam melakukan suatu prediksi.

\section{Penelitian Computational} Engineering yang diusulkan saat ini difokuskan pada model arsitektur Deep Neural Network (DNN) untuk prediksi atau estimasi kekuatan beton muda yang merupakan kelanjutan dari penelitian "Pemodelan Desain Campuran Beton dengan Neural Networks (2016)" yang hanya berfokus pada beton umur 28 hari.

Model ini sebagai inovasi baru Machine Learning di dunia Teknik Sipil dapat dengan mudah disesuaikan untuk berbagai komposisi campuran yang sangat beragam. Penggantian komposisi bahan dan campuran dapat diatasi dengan mudah karena model ini dapat belajar dari kondisi- kondisi baru yang belum pernah dijumpai sekalipun oleh model ini.

Model ini dapat diterapkan untuk mendesain berbagai bahan campuran beton dengan karakteristik yang berbeda. Bahan campuran yang berupa pasir atau kricak dari daerah satu dengan daerah yang lain sangat berbeda karakteristiknya. Namun demikian model ini dapat memprediksi kuat tekan yang nantinya dihasilkan setelah beton diproduksi secara insitu maupun oleh industri beton.

Ke depan berkaitan dengan industri beton, model ini dapat diterapkan untuk menciptakan Batching and Mixing Plant yang cerdas. Batching and Mixing Plant atau biasa disebut pula Tower Beton adalah tempat produksi ready mix atau beton curah siap pakai di pabrik/ industri beton (SIMEM, 2018). Saat ini otomasi yang ada pada Batching and Mixing Plant masih sangat sederhana, yakni dengan hanya menimbang bahan- bahan yang diperlukan sesuai desain campuran manual menggunakan microcontroller (Tosye Teknik. 2018). Desain campurannya masih menggunakan metode konvensional. Dengan model dari hasil penelitian ini nantinya dapat diciptakan perangkat otomasi yang cerdas yang mampu belajar menyesuaikan karakteristik bahan agar dihasilkan kuat tekan beton yang diinginkan.

\section{Computational Engineering State of The Art}

Beton merupakan perpaduan bahan pengisi dan pengikat (Setyawan 2017) seperti kerikil, pasir, semen, dan air yang dicampur dengan perbandingan tertentu (Chopra, 2016), (SNI 2013). (Tangchirapat 2013). Namun bahan tersebut tidak cukup untuk memproduksi beton yang berkualitas. Dalam perkembangannya sekarang muncul berbagai bahan beton baru dan perpaduan kimiawi baru guna memproduksi beton mutu sangat tinggi, self compacting (Najimi, 2012), (Husken, 2012), (Tangchirapat 2013), memiliki daktilitas tinggi (Wendner 2015), dan durabilitas tinggi.

Kekuatan rencana beton standar diukur pada umur 28 hari, padahal untuk keperluan pengawasan dan pengendalian diperlukan informasi kekuatan pada umur sebelumnya (Ray, 2016). Penting untuk dilakukan prediksi kuat tekan pada umur sebelum 28 hari. Informasi ini penting untuk 
digunakan saat konstruksi beton masih dalam proses pembangunan karena sering terjadi kegagalan karena pembebanan versus kekuatan beton yang sulit diprediksi saat beton masih muda.

Keragaman bahan dan perilaku beton ini menimbulkan banyak efek (Kurt 2016). Bahan yang sama bisa menghasilkan kuat tekan yang berbeda bila digunakan metode desain campuran yang berbeda (Najimi, 2012) termasuk juga self compacting, daktilitas, durabilitas, pengangkutan (Hui, 2013), dan curing yang berbeda pula. Hal ini menunjukkan perilaku beton sangat kompleks sehingga memunculkan beragam metode desain campuran yang sangat kompleks pula. Akibatnya hasil prediksi kuat tekan yang diperoleh tidak akurat.

Metode konvensional cenderung mengandalkan model analisis yang membutuhkan kondisi yang ideal dan presisi tinggi. Pada kenyataannya kondisi ini sulit untuk diperoleh. Selain itu juga metode konvensional membutuhkan bendabenda uji yang harus diuji secara destruktif (trial mix). Tes destruktif menimbulkan masalah baru karena bekas benda uji yang hancur akan mencemari lingkungan, membutuhkan biaya yang besar, dan tidak akurat. Walaupun ada cara nondestruktif yang menggunakan hammer atau UPV (Nobile, 2014) namun kurang valid.

Dalam perkembangannya beberapa peneliti telah melakukan uji coba model Computational Engineering desain campuran beton, baik untuk slump maupun kuat tekan, menggunakan linier regression, multiple linier regression, non linier regression, Adaptive Neural Fuzzy Inference Systems and Fuzzy Inference Systems, dan Artificial Neural Networks (ANN). Wen-Huan Chine dalam penelitiannya menyimpulkan bahwa ANN lebih akurat dalam memprediksi nilai slump pada rancangan campuran beton dibandingkan multiple linier regression (Chine, 2010). Kesimpulan yang sama terhadap ANN juga dinyatakan oleh Ashu Jain, bahwa ANN lebih akurat dalam melakukan estimasi. Hasil penelitian mereka, termasuk I-Cheng Yeh, menunjukkan bahwa ANN merupakan metode pemodelan yang lebih baik dan mampu memberikan akurasi prediksi yang lebih akurat dibandingkan linier regression, multiple linier regression, non linier regression (Jain, 2008; Yeh, 2007). I-Cheng Yeh juga mencoba pendekatan lain untuk memodelkan desain campuran untuk memprediksi kuat tekan beton, yakni menggunakan Genetic Operation Trees (GOT), ANN, dan Non-Linier Regression Analysis (NLRA). Hasilnya ANN lebih akurat dibanding pendekatan yang lain (Yeh, 2010). Bahador Abolpour membuat model estimasi kuat tekan beton dengan pendekatan Fuzzy Logic dengan menunjukkan hubungan antara desain campuran dengan hasil prediksi kuat tekan beton (Abolpour, 2013).

Pendekatanpendekatan statistik konvensional sudah banyak ditinggalkan, walaupun masih ada. State of the art dari konstelasi penelitian pemodelan prediksi kuat 
tekan beton adalah seperti yang disampaikan oleh Mehdi Nikoo tentang Prediction of Concrete Compressive Strength by Evolutionary Artificial Neural Networks. Penelitian ini melibatkan Genetic Algorithm (GA) untuk menentukan bobot yang optimal pada ANN (Nikoo. 2015).

Berdasarkan uraian di atas, maka penelitian ini dimaksudkan untuk menciptakan model prediksi kuat tekan beton dengan variasi umur beton muda dengan menggunakan Artificial Neural Network dengan arsitektur Deep Neural Network (DNN).

\section{Studi Pendahuluan}

Pemodelan yang dapat diandalkan untuk mengatasi kompleksitas masalah prediksi kuat tekan beton dengan formulasi desain campuran adalah melalui pendekatan Computational Intelligence (kecerdasan komputasi) untuk Data Mining. Pemodelan prediksi dalam Data Mining ini dapat melibatkan Machine Learning (Cattral, 2002) yang mirip kemampuan manusia dalam memecahkan suatu masalah melalui training dan application (Hertzmann, 2012), dan Evolutionary Algorithm (Freitas, 2003) (Mukhopadhyay, 2014) yang disebut pula Data Mining by Evolutionary Learning (Au, 2003).

Pendekatan yang termasuk soft computing ini (Maimon ed., 2008) mampu mengatasi hal- hal yang bersifat imprecision, uncertainty, partial truth, and approximation to achieve practicability, robustness and low solution cost (Gupta, 2013) seperti yang dijumpai saat proses desain campuran beton dilakukan.

Studi pendahuluan yang telah dilakukan penulis berkaitan dengan model ini adalah:

1. Pemodelan Desain Campuran Beton dengan Neural Networks (2015). Penelitian ini merupakan penelitian awal untuk menyusun model prediksi dengan hanya mengandalkan Neural Networks tanpa perlakuan evolusif. Prediksi dilakukan untuk beton berumur 28 hari.

2. Model Prediksi Slump Beton dengan Artificial Neural Networks (2016). Penelitian ini hampir sama dengan penelitian sebelumnya, namun model yang sudah diperoleh diterapkan pada kasus yang berbeda, yakni Slump Beton.

3. Model Prediksi Slump Beton dengan Artificial Neural Networks dan Optimasi Genetic Algorithm (2016). Penelitian ini mencoba pengaruh perlakuan evolusif Genetic Algorithm untuk memprediksi Slump. Hasil penelitian menunjukkan bahwa terdapat peningkatan akurasi yang signifikan dari model sebelumnya yang tidak evolusif.

4. Evolutionary Artificial Neural Networks for Concrete Mix Design Modelling (2017). Model komputasi yang telah diperoleh dari penelitian sebelumnya kemudian diaplikasikan untuk membuat model prediksi kuat tekan beton pada umur 28 hari.

Penelitian yang diusulkan ini merupakan tindak lanjut dari penelitian yang keempat, yakni dengan membuat 
dan menguji coba model prediksi beton pada umur 3, 7, 14, dan 28 hari dengan pendekatan Artificial Neural Networks tipe H2O's Deep Learning.

\section{METODE PENELITIAN}

Berdasarkan rumusan masalah yang sudah diuraikan di Pendahuluan, maka untuk memperoleh solusi atas masalah tersebut agar tujuan tercapai disusunlah strategi dan tahapan penelitian seperti berikut ini.

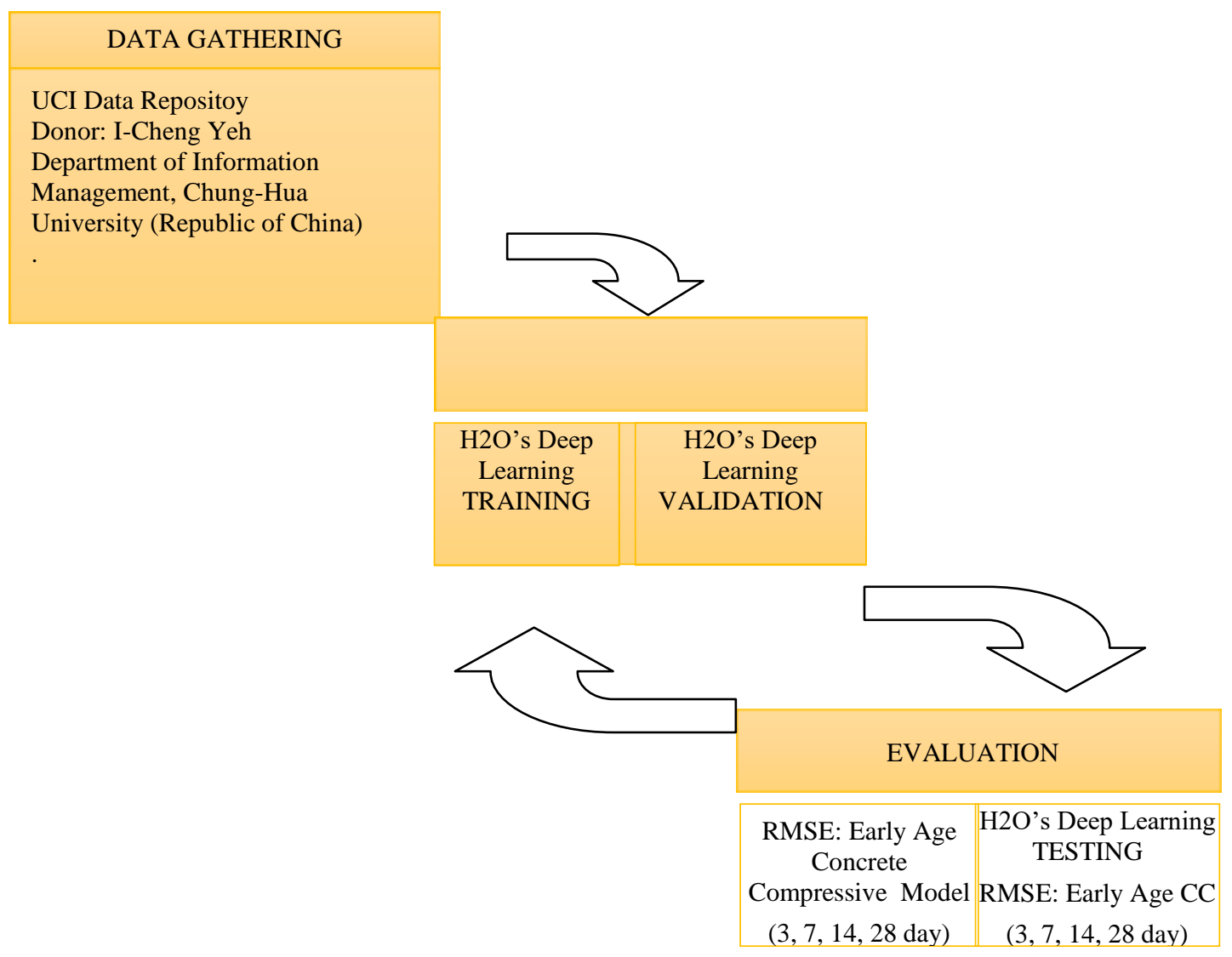

Gambar 1. Diagram Alir Metode Penelitian

Penelitian ini menggunakan $H 2 O$ 's Deep Learning yang didasarkan pada Multi-Layer Feedforward Artificial Neural Networks (ANN) yang dilatih dengan Stochastic Gradient Descent menggunakan BackPropagation. Jaringan dapat berisi sejumlah besar lapisan tersembunyi yang terdiri dari neuron dengan fungsi aktivasi Tanh, Rectifier, dan Maxout. Fitur-fitur seperti adaptive learning rate, rate annealing, momentum training, dropout, L1 or L2 regularization, checkpointing, and grid search memungkinkan diperolehnya akurasi prediksi yang tinggi.

\section{Pengumpulan Data}

Data sekunder diperoleh dari UCI Data Repository berupa data desain campuran beton manual yang telah diuji coba pada berbagai mutu dan umur beton untuk memperoleh nilai kuat tekan (concrete compressive 
strength dalam satuan $\mathrm{MPa}$ ). Komposisi campuran divariasikan berdasarkan perbandingan bahan yang terdiri dari Cement, Blast Furnace Slag, Fly Ash, Water, Superplastizicer, Coarse Aggregate, Fine Aggregate, dan Age (3, 7, 14, 28 hari).

\section{Eksperimen}

Proses belajar pada jaringan ini terjadi dengan memberikan data yang disebut training data atau training vectors. Sebelumnya dilakukan pembagian data (data split) yang terdiri training data dan validation data yang digunakan untuk membuat model, dan testing data untuk menguji model yang terbentuk. Validation data, digunakan untuk proses validasi model dan mencegah overfitting.

Training dan validasi ini menggunakan Cross Validation yang membagi data hasil data split ke dalam $k$ subset yang sama dimensinya. Data sejumlah (k-1) digunakan untuk training dan sejumlah 1 (satu) subset digunakan untuk testing secara bergantian.

Model komputasi Deep Neural Network (DNN) yang merupakan salah satu jenis algoritma Artificial Neural Networks (ANN) dibentuk berdasarkan nilai Hyperparameter awal berupa Jumlah Hidden Layer dan Hidden Neuron. Parameter lainnya berupa bobot dan nilai bias, Training Cycle, Learning Rate, Momentum. Output dari proses ini adalah nilai prediksi Concrete Compressive Strength yang dibandingkan terhadap validation data agar terukur error-nya, dalam hal ini Root Mean Square Error (RMSE).

\section{Evaluasi}

Setelah jaringan memperoleh pembelajaran melalui training dan validasi, maka langkah berikutnya adalah evaluasi model melalui proses pengujian untuk menguji coba model yang terbentuk. Data pengujian diambil dari segmen yang berbeda dengan data training dan validasi yang telah dipisahkan sebelumnya. Atribut datanya sama dengan data training dan validasi berupa jumlah Cement, Blast Furnace Slag, Fly Ash, Water, Superplastizicer, Coarse Aggregate, Fine Aggregate, dan Age (3, 7, 14, 28 hari) yang digunakan untuk menguji nilai Compressive Strength dalam berbagai umur beton muda. Hasil evaluasi berupa nilai RMSE yang menunjukkan tingkat kesalahan model.

\section{HASIL PENELITIAN DAN PEMBAHASAN}

H2O's Deep Learning merupakan Deep Neural Network (DNN) atau Multi-Layer Perceptron (MLP) yang didasarkan pada Multi-Layer Feedforward Artificial Neural Networks yang dilatih dengan Stochastic Gradient Descent menggunakan Back-Propagation. Hyperparameter berupa jumlah Hidden Layer (HL) dan Hidden Neuron (N) yang dapat diujicoba dalam berbagai arsitektur.

Penelitian ini diawali dengan menggunakan arsitektur 2 Hidden Layer (HL) dengan 50 Hidden Neuron (N), 4 HL-50 N, 6 HL-50 N, 9 HL-50 $\mathrm{N}, 12$ HL-50 N, 15 HL-50 N. Hasil percobaan awal adalah sebagai berikut. 


\begin{tabular}{lr|r}
$\begin{array}{l}\text { Variasi HL ReLU } \\
\text { DeepL }\end{array}$ & $\begin{array}{l}\text { xValidated } \\
\text { Model }\end{array}$ & $\begin{array}{l}\text { Testing } \\
\text { Model }\end{array}$ \\
\hline 2HL50N 0.6/0.4 & 7,195 & 6,801 \\
4HL50N 0.6/0.4 & 7,428 & 7,125 \\
\hline 6HL50N 0.6/0.4 & 7,599 & 7,121 \\
9HL50N 0.6/0.4 & 7,902 & 7,510 \\
12HL50N 0.6/0.4 & 8,395 & 7,402 \\
15HL50N 0.6/0.4 & 8,915 & 7,642 \\
\hline
\end{tabular}

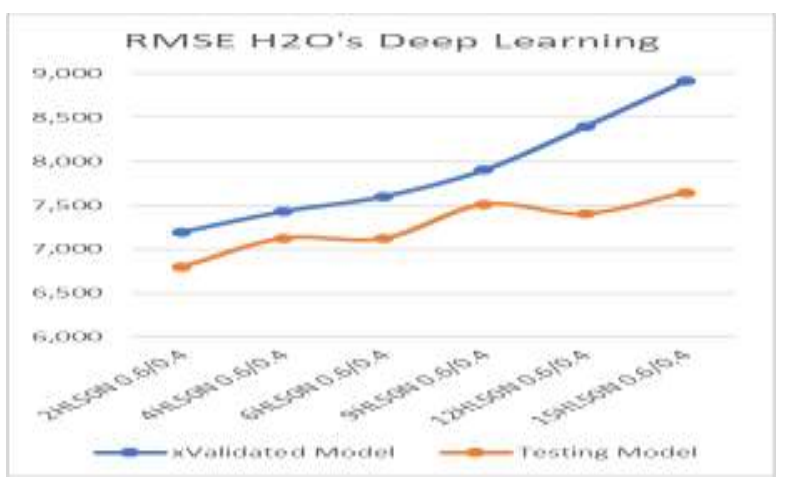

Gambar 2. Model H2O's Deep Learning dengan Variasi Jumlah Hidden Layer

Hasil penelitian menunjukkan bahwa nilai RMSE terendah diperoleh pada model 2 Hidden Layer (HL) dengan 50 Hidden Neuron (N) dengan data split yang diterapkan adalah 0,6 untuk training dan 0,4 untuk testing. RMSE Model Training diperoleh sebesar 7,195 sedangkan Model Testing sebesar 6,801. Hal ini menunjukkan bahwa kedalaman jaringan tidak selalu menjamin

\begin{tabular}{lrr} 
Variasi Neuron & \multicolumn{1}{c}{ xValidated } & \multicolumn{2}{l}{ Testing } \\
DeepL ReLU & \multicolumn{1}{l}{ Model } & \multicolumn{2}{l}{ Model } \\
\hline 2HL8N 0.6/0.4 & 7,426 & 6,864 \\
2HL10N 0.6/0.4 & 7,369 & 7,462 \\
2HL30N 0.6/0.4 & 7,016 & 7,030 \\
2HL50N 0.6/0.4 & 7,195 & 6,801 \\
2HL80N 0.6/0.4 & 7,015 & 6,858 \\
2HL100N 0.6/0.4 & 7,694 & 7,365
\end{tabular}

terbentuknya model yang optimal. Model dengan kedalaman jaringan hingga $15 \mathrm{HL}$ justru memperlihatkan RMSE yang paling tinggi, yakni 8,915. Eksperimen selanjutnya adalah menguji jumlah Hidden Neuron (N) yang paling efektif. Jumlah Hidden Neuron (N) yang diujikan mulai dari 8 $\mathrm{N}$ (sama dengan jumlah node pada layer input), $10 \mathrm{~N}, 30 \mathrm{~N}, 50 \mathrm{~N}, 80 \mathrm{~N}$, dan 100 N. Hasilnya sebagai berikut.

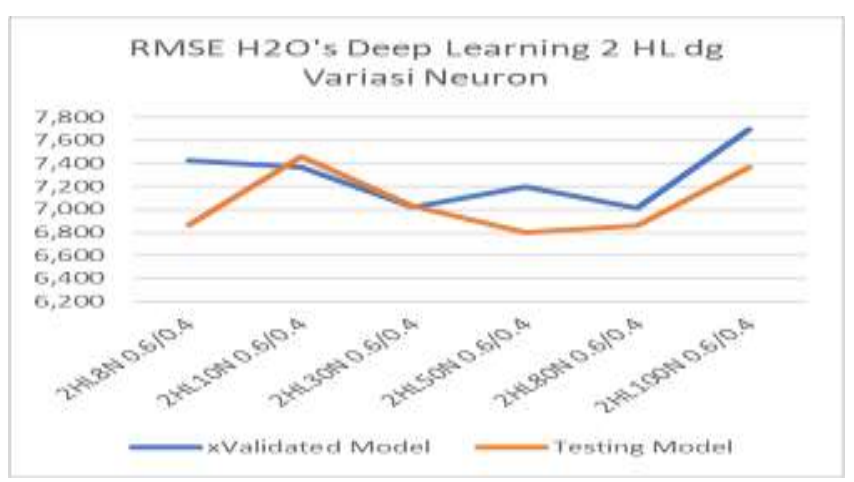

Gambar 3. Model H2O's Deep Learning dengan Variasi Jumlah Hidden Neuron

Nilai RMSE terendah diperoleh pada Model Training dengan 2 Hidden Layer (HL) -30 Hidden Neuron (N) dan 80 Hidden Neuron $(\mathrm{N})$ dengan nilai RMSE 7,016 dan 7,015 sedangkan Model Testing sebesar 6,801 pada 2 Hidden Layer (HL) -50
Hidden Neuron (N). RMSE pada Model Training tidak terlalu berbeda pada jumlah Hidden Neuron (N) 30, 50 , dan 80 yang setelah dilakukan pengujian ternyata yang paling optimal adalah 50 neuron. Meskipun demikian masih perlu dilakukan pengujian 
terhadap peran fungsi aktivasi dalam mempengaruhi nilai RMSE.

Eksperimen selanjutnya adalah menguji efektivitas fungsi aktivasi rectified linear unit (ReLU) dan hyperbolic tangent (tanh) pada arsitektur 2 HL-50 N, 4 HL-50 N, 6 HL-50 N, 9 HL-50 N, 12 HL-50 N, 15 HL-50 N. Hasilnya sebagai berikut.

\begin{tabular}{lrr} 
Variasi HL & \multicolumn{1}{l}{ ReLU } & \multicolumn{1}{c}{ TanH } \\
DeepL & xVal & \multicolumn{1}{l}{ xVal } \\
2HL50N 0.6/0.4 & 7,195 & 7,323 \\
4HL50N 0.6/0.4 & 7,428 & 7,908 \\
6HL50N 0.6/0.4 & 7,599 & 8,130 \\
9HL50N 0.6/0.4 & 7,902 & 8,017 \\
12HL50N 0.6/0.4 & 8,395 & 8,304 \\
15HL50N 0.6/0.4 & 8,915 & 8,432
\end{tabular}

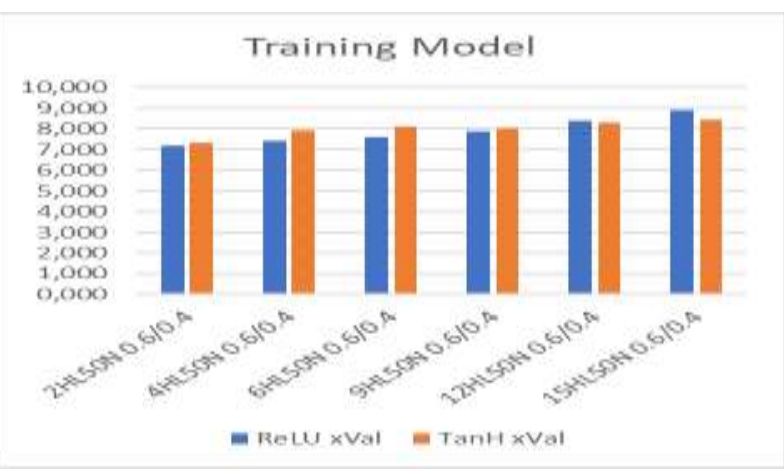

Gambar 4. Perbandingan Fungsi Aktivasi ReLU dan tanh pada Training Model H2O's Deep Learning

Pada saat training, model terbaik dibangun dengan menggunakan fungsi aktivasi ReLU dengan nilai RMSE 7,195 yang berbeda tidak jauh dengan fungsi aktivasi tanh dengan nilai RMSE 7,323. Model yang terbentuk ini kemudian diuji dengan data uji di luar data training hingga diperoleh nilai RMSE sebagai berikut.

\begin{tabular}{lrr} 
Variasi HL & \multicolumn{1}{l}{ ReLU } & \multicolumn{1}{l}{ TanH } \\
DeepL & \multicolumn{1}{l}{ Test } & \multicolumn{1}{l}{ Test } \\
2HL50N 0.6/0.4 & 6,801 & 7,586 \\
4HL50N 0.6/0.4 & 7,125 & 7,361 \\
6HL50N 0.6/0.4 & 7,121 & 7,173 \\
9HL50N 0.6/0.4 & 7,510 & 8,066 \\
12HL50N 0.6/0.4 & 7,402 & 8,211 \\
15HL50N 0.6/0.4 & 7,642 & 8,263
\end{tabular}

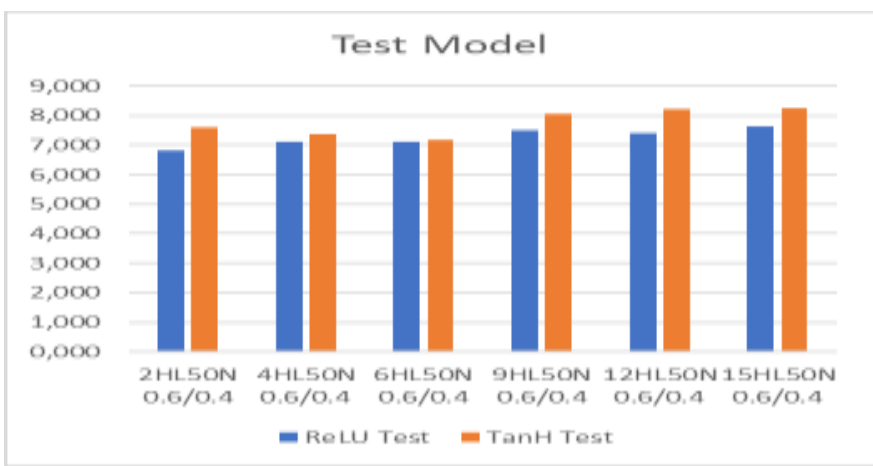

Gambar 5. Perbandingan Fungsi Aktivasi ReLU dan tanh pada Testing Model H2O's Deep Learning dengan Variasi Jumlah Hidden Layer

Penggunaan fungsi aktivasi menghasilkan RMSE 7,173 pada rectified linear unit (ReLU) arsitektur $6 \mathrm{HL} 50$ neuron. Hasil menghasilkan RMSE 6,801 pada percobaan ini menunjukkan bahwa arsitektur 2 HL 50 neuron dan fungsi aktivasi ReLU memiliki hasil hyperbolic tangent (tanh) yang lebih baik daripada tanh. 
Meskipun demikian hal ini tidak bisa dijadikan kesimpulan bahwa fungsi aktivasi ReLU lebih bagus daripada tanh karena belum diketahui jumlah neuron yang paling efektif.

Percobaan berikutnya adalah menguji fungsi aktivasi ReLU dan tanh dengan variasi jumlah neuron pada jumlah hidden layer yang sama, yakni
2 HL untuk Training Model. Arsitektur 2 HL dipilih karena menghasilkan RMSE yang terendah dibandingkan sejumlah hidden layer yang lain, dengan perbedaan jumlah neuron mulai dari $8 \mathrm{~N}, 10 \mathrm{~N}, 30 \mathrm{~N}, 50$ $\mathrm{N}, 80 \mathrm{~N}$, hingga $100 \mathrm{~N}$. Berikut ini adalah hasil percobaan pada Training Model.

\begin{tabular}{lrr} 
Variasi Neuron & ReLU & \multicolumn{1}{l}{ TanH } \\
pada 2HL DeepL & \multicolumn{1}{c}{ xVal } & \multicolumn{1}{l}{ xVal } \\
2HL8N 0.6/0.4 & 7,426 & 7,494 \\
2HL10N 0.6/0.4 & 7,567 & 7,400 \\
2HL30N 0.6/0.4 & 7,016 & 7,223 \\
2HL50N 0.6/0.4 & 7,195 & 7,323 \\
2HL80N 0.6/0.4 & 7,015 & 7,637 \\
2HL100N 0.6/0.4 & 7,694 & 7,694
\end{tabular}

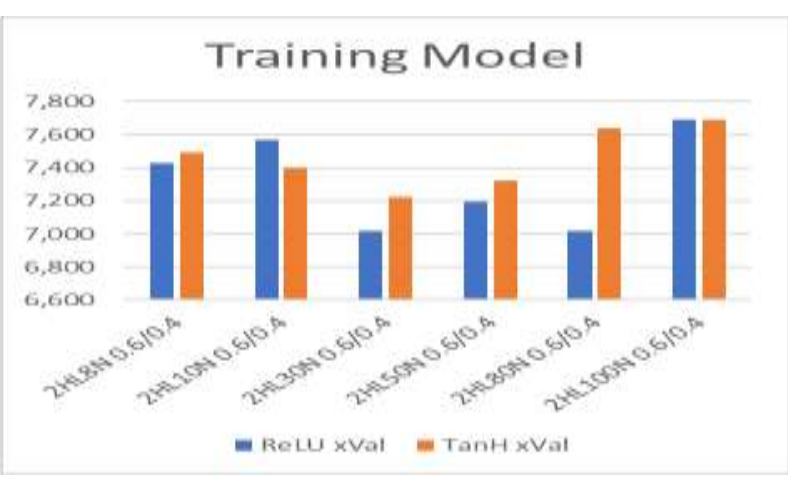

Gambar 6. Perbandingan Fungsi Aktivasi ReLU dan tanh pada Training Model H2O's Deep Learning

Dari percobaan tersebut diperoleh performa terbaik adalah fungsi aktivasi ReLU daripada tanh pada arsitektur 2 HL dengan 30 hingga 50 neuron dengan RMSE sekitar 7,01. Fungsi aktivasi tanh menghasilkan RMSE 7,223 pada arsitektur $2 \mathrm{HL}$ dengan 30 neuron. Testing Model dengan arsitektur tersebut di atas memperoleh hasil seperti Gambar 7 di bawah.

Dari percobaan pada arsitektur dengan kedalaman $2 \mathrm{HL}$ dengan variasi jumlah neuron mulai dari 8 $\mathrm{N}, 10 \mathrm{~N}, 30 \mathrm{~N}, 50 \mathrm{~N}, 80 \mathrm{~N}$, hingga 100 $\mathrm{N}$ diperoleh hasil fungsi aktivasi ReLU lebih bagus daripada tanh dengan nilai RMSE 6,801 pada 2 HL-50 N. Fungsi aktivasi tanh menghasil RMSE 6,818 pada 2 HL-10N. Satu hal yang patut diperhatikan adalah munculnya jumlah neuron yang lebih sedikit daripada percobaan- percobaan terdahulu, yakni hanya 10 neuron pada fungsi aktivasi tanh. Pada percobaan- percobaan terdahulu efektivitas sering tercapai pada jumlah 50 neuron. Belum ada ketentuan yang memastikan jumlah neuron terbaik untuk memperoleh nilai kesalahan terendah dari suatu model, tetapi penggunaan neuron yang terlalu banyak sangat berpegaruh pada lamanya waktu proses.

Percobaan- percobaan di atas dilakukan dengan split data 0,6 berbanding 0,4 masing- masing 0,6 untuk data training dan 0,4 untuk data testing. Pembagian data ini 
kemungkinan berpengaruh pada nilai RMSE. Oleh sebab itu dilakukan eksperimen berikut ini untuk mengetahui pengaruh pembagian data dengan membandingkan split data 0,6 berbanding 0,4 dengan split data 0,7 berbanding 0,3 .

$\begin{array}{llr}\text { Variasi Neuron } & \text { ReLU } & \\ \text { pada 2HL DeepL } & \text { Test } & \text { TanH Test } \\ \text { 2HL8N 0.6/0.4 } & 6,864 & 7,114 \\ \text { 2HL10N 0.6/0.4 } & 7,410 & 6,818 \\ \text { 2HL30N 0.6/0.4 } & 7,030 & 6,954 \\ \text { 2HL50N 0.6/0.4 } & 6,801 & 7,586 \\ \text { 2HL80N 0.6/0.4 } & 6,858 & 7,371 \\ \text { 2HL100N 0.6/0.4 } & 7,365 & 7,668\end{array}$

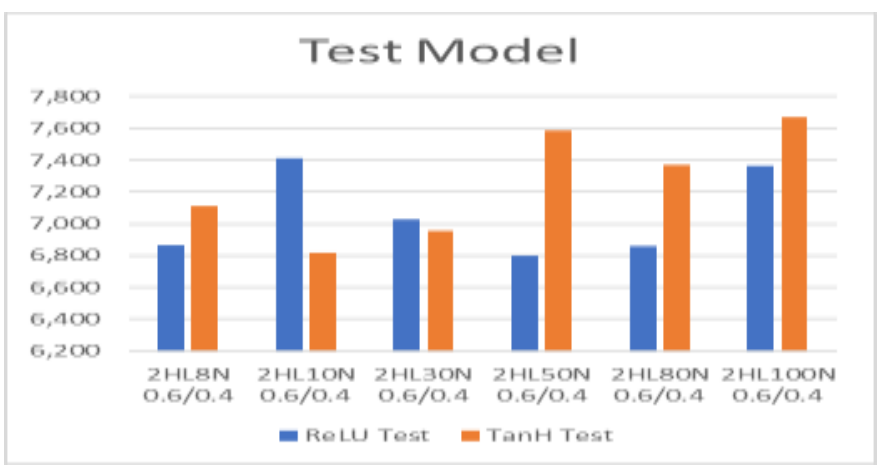

Gambar 7. Perbandingan Fungsi Aktivasi ReLU dan tanh pada Testing Model H2O's Deep Learning

ReLU

$\begin{array}{llr}\text { Split Data } & \text { Test } & \text { TanH Test } \\ \text { 2HL8N 0.6/0.4 } & 6,864 & 7,114 \\ \text { 2HL10N 0.6/0.4 } & 7,410 & 6,818 \\ \text { 2HL30N 0.6/0.4 } & 7,030 & 6,954 \\ \text { 2HL50N 0.6/0.4 } & 6,801 & 7,586 \\ \text { 2HL80N 0.6/0.4 } & 6,858 & 7,371 \\ \text { 2HL100N 0.6/0.4 } & 7,365 & 7,668 \\ \text { 2HL8N 0.7/0.3 } & 6,885 & 6,987 \\ \text { 2HL10N 0.7/0.3 } & 7,314 & 7,315 \\ \text { 2HL30N 0.7/0.3 } & 6,821 & 7,036 \\ \text { 2HL50N 0.7/0.3 } & 6,931 & 7,304 \\ \text { 2HL80N 0.7/0.3 } & 7,173 & 7,461 \\ \text { 2HL100N 0.7/0.3 } & 7,098 & 7,711\end{array}$

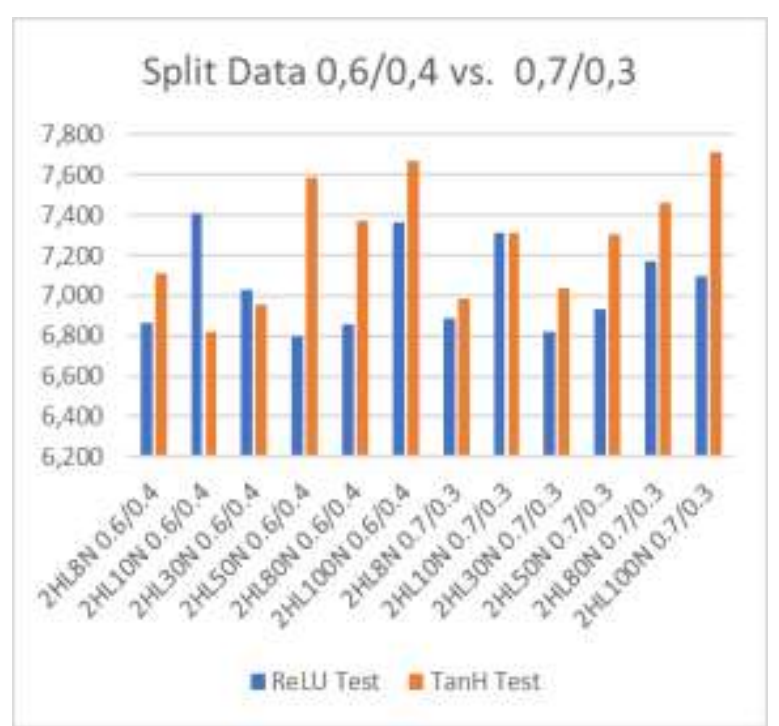

Gambar 8. Perbandingan RMSE Model dengan Split Data 0,6/0,4 vs. 0,7/0,3 pada Fungsi Aktivasi ReLU dan tanh

Hasil percobaan menunjukkan bahwa split data 0,6 berbanding 0,4 menunjukkan nilai RMSE yang lebih rendah pada fungsi aktivasi ReLU dan arsitektur 2 Hidden Layer (HL) dengan 50 Hidden Neuron (N), yakni dengan nilai RMSE sebesar 6,801. Fungsi aktivasi tanh memiliki RMSE yang lebih tinggi, yakni sebesar 6,821 pada arsitektur 2 Hidden Layer (HL) dengan 10 Hidden Neuron (N).

Pada split data 0,7 berbanding 
0,3 fungsi aktivasi ReLU dan arsitektur

2 Hidden Layer (HL) dengan 30 Hidden Neuron (N) juga menunjukkan nilai RMSE yang lebih rendah daripada fungsi aktivasi tanh, yakni dengan nilai RMSE sebesar 6,821. Fungsi aktivasi tanh memiliki RMSE yang lebih tinggi, yakni sebesar 6,987 pada arsitektur 2 Hidden Layer (HL) dengan 8 Hidden Neuron (N).

Dari aspek parameter yang berupa fungsi aktivasi dapat disimpulkan bahwa fungsi aktivasi ReLU menyumbangkan tingkat kesalahan yang lebih rendah daripada fungsi aktivasi tanh. Dari aspek split data dapat disimpulkan bahwa data training sebanyak $70 \%$ menyumbangkan tingkat kesalahan yang lebih tinggi daripada data training sebanyak $60 \%$. Hal ini menunjukkan bahwa pada kasus ini training yang melibatkan data yang lebih banyak tidak selalu menjamin terbentuknya model yang lebih baik. Bahkan ada kemungkinan training yang melibatkan data yang lebih banyak akan menimbulkan overfitting. Data yang lebih banyak kemungkinan akan mengandung noise yang lebih banyak pula walaupun tidak selalu demikian. Namun apabila noise cukup besar dan proses training tidak mampu mengabaikannya akibatnya akan terjadi low loss sehingga tingkat kesalahan semakin tinggi.

Dari serangkaian eksperimen di atas dapat disimpulkan bahwa model terbaik yang mampu dihasilkan $\mathrm{H} 2 \mathrm{O}$ 's Deep Learning adalah arsitektur 2 Hidden Layer (HL) -50 Hidden Neuron (N) dengan data split yang diterapkan adalah 0,6 untuk training dan 0,4 untuk testing dan dengan fungsi aktivasi ReLU dengan nilai RMSE sebesar 6,801 .

\section{SIMPULAN}

Berkaitan dengan eksperimen yang telah dilakukan guna pemecahan masalah dan pencapaian tujuan penelitian, maka dapat diambil beberapa kesimpulan bahwa model terbaik prediksi desain campuran beton muda yang mampu dihasilkan H2O's Deep Learning adalah arsitektur 2 Hidden Layer (HL) -50 Hidden Neuron (N) dengan data split yang diterapkan adalah 0,6 untuk training sedangkan 0,4 untuk testing dan fungsi aktivasi ReLU dengan nilai RMSE sebesar 6,801. Pada kasus ini training yang melibatkan data yang lebih banyak tidak selalu menjamin terbentuknya model yang lebih baik. Bahkan ada kemungkinan training yang melibatkan data yang lebih banyak akan menimbulkan overfitting.

Kedalaman jaringan yang diujicobakan mulai 2 hingga 15 Hidden Layer menunjukkan kedalaman dengan 2 Hidden Layer adalah yang terbaik. Model dengan kedalaman jaringan hingga $15 \mathrm{HL}$ pada kasus ini justru memperlihatkan RMSE yang paling tinggi. Kedalaman jaringan tidak selalu menjamin terbentuknya model yang optimal. Jumlah Hidden Neuron yang diujicobakan pada penelitian ini mulai dari 8 neuron hingga 100 neuron. Namun jumlah neuron optimal yang memberikan nilai RMSE terendah pada kasus ini hanya 10 neuron. Belum ada ketentuan yang 
memastikan jumlah neuron terbaik untuk memperoleh nilai kesalahan terendah dari suatu model, tetapi penggunaan neuron yang terlalu banyak sangat berpegaruh pada lamanya waktu proses.

\section{DAFTAR PUSTAKA}

Abolpour, B, Benafsheh Abolpour, Roozbeh Abolpour, Hossein Bakhshi, 2013, Estimation Of Concrete Compressive Strength By A Fuzzy Logic Model, Science+Business Media B.V, Springer. 2013.

Au, W.H., Chan, K.C.C. Yao, X.Y., 2003, A Novel Evolutionary Data Mining Algorithm With Applications To Churn Prediction. Ieee Transactions On Evolutionary Computation, Vol. 7, No. 6, December 2003.

Cattral, R., Oppacher, F., Deugo, D., 2002, Evolutionary Data Mining With Automatic Rule Generalization.

Https://Pdfs.Semanticscholar.Or g/C068/Ea7807367573f4b5f98c0 681fca665e9e F74.Pdf. Diakses Tanggal 21 Februari 2018.

Chine, Wh. Li Chen. Hsun-Hsin Hsu. Tai-Seng Wang, 2010, Modeling Slump Of Concrete Using The Artificial Neural Networks, International Conference On Artificial Intelligence And Computational Intelligence, 2010, P.236-239, Ieee Computer Society.

Chopra, P., Rajendra Kumar Sharma, Maneek Kumar, 2016, Prediction Of Compressive Strength of
Concrete Using Artificial Neural Network And Genetic Programming, Advance Material Scienceanda Engineering Vol 2016 Article Id 7648467, Hindawi Pub Corporate.

Freitas, A.A., 2003, A Survey Of Evolutionary Algorithms For Data Mining And Knowledge Discovery.

Http://Neuro.Bstu.By/Our/Data-

Mining/Fereitas-Ga.Pdf.

Gupta, P., \& Kulkarni, N., 2013, An Introduction Soft Computing Over Hard Computing. International Journal of Latest Trends In Engineering And Technology (Ijltet), Vol. 3 Issue 1 September 2013.

Hertzmann, A., \& Fleet, D, 2012, Univ Toronto-Machine Learning And Data Mining, Computer Science Department, University Of Toronto, Version: February 6, 2012.

Hui, C. Zhenyu, L., 2013, Research On The Experiment Of Self Leveling Concrete With Fly Ash.2013 Fifth Conference On Measuring Technology And Mechatronics Automation.

Husken, G., H.J.H. Brouwers, 2012, On The Early-Age Behavior of Zero-Slump Concrete, Cement And Concrete Research, Vol 42 (2012) 501-510, Elsevier.

Jain, A., Jha, S.K., \& Misra, S., 2008, Modeling And Analysis Of Concrete Slump Using Artificial Neural Networks, P 628-633. Journal Of Materials In Civil Engineering (C) Asce / September 
2008.

Kurt, M., Kotan, T., Gül, M.S., Gül, R., Aydin, A.C., 2016, The Effect Of Blast Furnace Slag On The Self-Compactability Of Pumice Aggregate Lightweight Concrete. Sadhana, ${ }^{-}$Vol. 41, No. 2, February 2016, Pp. 253264.

Maimon, O., \& Rokach, L., Ed., 2008, Soft Computing For Knowledge Discovery And Data Mining. Library Of Congress Control Number: 2007934794, Isbn 9780-387-69934-9 E- Isbn 978-0387-69935-6, (C) 2008 Springer Science+Business Media, Llc.

Mukhopadhyay, A., $\quad \&$

Bandyopadhyay, S., 2014, Survey Of Multiobjective Evolutionary Algorithms For Data Mining Part I. Ieee Transactions On Evolutionary Computation, Vol. 18, No. 1, February 2014.

Najimi, M., J. Sobhani, A.R. Pourkhorshidi, 2012, A Comprehensive Study On Noslump Concrete: From Laboratory Towards

Manufactory, Construction And Building Material Vol 30 (2012) 529-536, Elsevier.

Nikoo. Mehdi. Farshid Torabian Moghadam. And Aukasz Sadowski, 2015, Prediction Of Concrete Compressive Strength By Evolutionary Artificial Neural Networks. Advances In Materials Science And Engineering Volume (2015. Article Id 8491(26. 8 Pages.
Hindawi Publishing Corporation. Nobile, L., 2014, Prediction Of Concrete Compressive Strength By Combined Non-Destructive Methods. Meccanica, (2015) 50:411-417, Doi 10.1007/S11012-014-9881-5

Ray, N., Dedi, P., Rizky, D., 2016, Studi Angka Koefisien Korelasi Kuat Tekan Beton Mutu Tinggi Berdasarkan Umur \& Bentuk Benda Uji Standar Sni 03-28472002. Agregat Issn: $2541-0318$, Vol.1 , No.1, November 2016.

Setyawan, Sigit, 2017, Software

Perancangan Campuran (Mix

Design) Beton Dengan Bahasa Pemograman Python Berbasis Gui (Graphical User Interface), Jurusan Teknik Sipil Fakultas Teknik, Universitas Muhammadiyah Surakarta.

Simem, 2018, Tower Beton - Vertical Batching And Mixing Plants. Https://Www.Euromarket.Bg/Bg /Products-Download-

Pdf?File...Pdf. Diakses Tanggal 2 Maret 2018.

SNI 2847-2013, Persyaratan Beton Struktural Untuk Bangunan

Gedung, Badan Standarisasi Nasional.

Takisawa, 2014, Computational Engineering Analysis With The New-Generation Space-Time Methods. Computational Mechanics, August 2014, Volume 54, Issue 2, Pp 193-211

Tangchirapat, W. Chaiyanunt Rattanashotinunt, Rak Buranasing, Chai Jaturapitakkul, 2013, Influence Of Fly Ash On 
Slump Loss And Strength Of Concrete Fully Incorporating Recycled Concrete Aggregates, Journal Of Materials In Civil Engineering February 2013, Asce.

Tosye Teknik, 2018, Proposal Otomasi

Batching Plan (Ready Mix \& Precast Concrete).

University Of Texas, 2018, Computational Engineering Solving 21st Century Engineering Problems

Wendner, R., et. al., 2015, Characterization of Concrete Failure Behavior, A Comprehensive Experimental Database For The Calibration And Validation of Concrete Models, Materials And
Structures, (2015) 48:3603-3626. Rilem.

Yeh. Ic., 2007, Modeling Slump Flow Of Concrete Using Second-Order Regressions And Artificial Neural Networks, Cement \& Concrete Composites 29, 2007, P.474-480. Elsevier.

Yeh. I.C. Che-Hui Lien. Chien-Hua Peng. Li-Chuan Lien, 2010, Modeling Concrete Strength Using Genetic Operation Trees. Proceedings Of The Ninth International Conference On Machine Learning And Cybernetics. Qingdao. 11-14 July (2010). IEEE 